\title{
PENERAPAN MODEL PEMBELAJARAN PROBING PROMPTING UNTUK MENINGKATKAN KEMAMPUAN BERPIKIR KRITIS SISWA MADRASAH IBTIDAIYAH
}

\author{
Teni Anisah ${ }^{1}$, Yayan Carlian ${ }^{1}$ \\ ${ }^{1} J u r u s a n$ Pendidikan Guru Madrasah Ibtidaiyah, UIN Sunan Gunung Djati, Bandung \\ tenianisah1@gmail.com
}

Naskah diterima: 16 Juli, 2020, direvisi: 29 Juli, 2020, diterbitkan: 30 Agustus, 2020

\begin{abstract}
This study aims to determine students' critical thinking skills before applying probing prompting learning models to natural science learning, and to know about the learning process by using probing prompting learning models in natural science learning as well as to determine students' critical thinking skills using probing prompting learning models in natural science learning. The research method used is the Clasroom Action Research (CAR) which consists of four stages, namely, planning, implementation, and reflection. The approach used is qualitative and quantitative approach. Data collection techniques were carried out by providing tests to determine students' critical thinking skills and through the activity observation sheet instrument with research subjects, students at class V Madrasah Ibtidaiyah (MI)/ Islamic School Darul Ulum Bandung, Indonesia. The total of respondents is 21 students consisting of 8 male students and 13 female students. Based on the result of the study, that students' critical thinking skills by using the probing prompting learning model on natural science learning has increased. This is based on the results of tests given in the first and second cycles obtained an average value of 49,06 and 61,11 with the percentage of classical learning completeness obtained in the first and second cycles of 33,33\% and 66,67\%. So, it can be concluded that the probing prompting learning model can improve students' critical thinking skills in science learning in the class.
\end{abstract}

Keywords: Critical Thinking, Probing Prompting, Science, Madrasah Ibtidaiyah

\begin{abstract}
ABSTRAK
Penelitian ini bertujuan untuk mengetahui kemampuan berpikir kritis siswa sebelum diterapkan model pembelajaran probing prompting pada pembelajaran IPA, gambaran proses pembelajaran dengan menggunakan model pembelajaran probing prompting pada pembelajaran IPA serta untuk mengetahui kemampuan berpikir kritis siswa dengan menggunakan model pembelajaran Probing Prompting pada pembelajaran IPA. Metode penelitian yang digunakan ialah Penelitian Tindakan Kelas (PTK) yang terdiri dari empat tahap secara berulang, yakni perencanaan, pelaksanaan, observasi, dan refleksi. Pendekatan yang digunakan yaitu pendekatan kualitatif dan kuantitatif. Teknik pengumpulan data dilakukan dengan memberikan tes untuk mengetahui kemampuan berpikir kritis siswa dan melalui instrument lembar observasi aktivitas dengan subjek penelitian yaitu siswa kelas V MI Darul Ulum Kabupaten Bandung dengan jumlah siswa sebanyak 21 orang yang terdiri dari 8 siswa laki-laki dan 13 siswa perempuan. Berdasarkan hasil penelitian, bahwa kemampuan berpikir kritis siswa dengan menggunakan model pembelajaran probing prompting pada pembelajaran IPA mengalami peningkatan. Hal ini berdasarkan hasil tes yang diberikan pada siklus I dan II diperoleh rata-rata nilai sebesar 49,06 dan 61,11 dengan persentase ketuntasan belajar klasikal yang diperoleh pada siklus I dan II yaitu 33,33\% da 66,67\%. Sehingga dapat disimpulkan bahwa model pembelajaran Probing Prompting dapat meningkatkan kemampuan berpikir kritis siswa pada pembelajaran IPA di kelas V MI Darul Ulum.
\end{abstract}

Kata Kunci: Berpikir kritis, IPA,Probing Prompting, Madrasah Ibtidaiyah 


\section{PENDAHULUAN}

Menurut (Wijaya dkk, 2016) kemampuan pada abad 21 yang dibutuhkan adalah keahlian teknologi serta sarana yang berupa fakta, pengetahuan dan membiasakan melakukan perbaikan yang didalamnya meliputi berpikir kritis dan mengatasi persoalan. Untuk melatih kemampuan berpikir kritis, siswa harus didorong dengan menjawab pertanyaan-pertanyaan yang berkaitan dengan hal-hal sebagai berikut: 1) memikirkan suatu akibat dari suatu permasalahan; 2) mengenali pendapat dari suatu pernyataan; 3) menyusun poin-poin dalam suatu permasalahan; 4) menemukan adanya perbedaan pada setiap sudut pandang; 5) mampu menjelaskan pemicu suatu kejadian; serta 6) memilih hal-hal yang mendukung atas suatu keputusan (Langrehr, 2006). Arifin (2017) juga mengatakan ciri dari sistem pembelajaran abad 21 ini siswa merupakan subyek dari prosedur pengkajian yang bukan sekedar mendengarkan serta menghafal materi belaka, tetapi berupaya demi menggali pengetahuannya sendiri sesuai dengan minat dan potensi yang dimilikinya.

Begitupun pada pembelajaran IPA, kemampuan berpikir kritis sangat penting karena pembelajaran IPA bukan hanya dalam hal penguasaan pengetahuan yang berupa konsep, fakta atau prinsip saja tetapi merupakan sebuah konsep penemuan (Widani dkk, 2019). Maka dari itu, kemampuan berpikir kritis adalah salah satu upaya yang dapat memberikan kontribusi untuk bisa memecahkan berbagai masalah yang dialami dalam kehidupan seharihari (Suparya, 2018). Oleh karena itu, Yulianti (2017) mengemukakan bahwa diperlukan cara pembelajaran yang dapat menyiapkan peserta didik untuk memiliki kompetensi yang baik dan melek sains serta teknologi, mampu berpikir logis, kritis, kreatif, berargumentasi secara benar, dapat berkomunikasi serta berkolaborasi. Adapun tahapan dalam berpikir kritis menurut menurut Butcher, Larson, \& Lane (Hidayah \& Suparman, 2019) yaitu: a). Observing (menyelidiki bukti), b). Connecting (mengaitkan pada pandangan lain dengan sesuai), c). Problem-finding (mengidentifikasi persoalan), d). Flexible Thinking (memperhitungkan semua bentuk pemecahan masalah), e). Evaluating (menentukan peluang untuk jalan keluar), f). Comparing and contrasting (mencocokan bentuk, perbandingan serta keselarasan dari jenis sumber fakta), g). Interpreting (menyimpulkan).

Menurut UNDP mengenai indeks pengembangan manusia (Human Development Index), pada tahun 2017 indonesia berada di posisi ke 116 dari 189 negara di dunia (Sari dkk, 2018). Hasil Trends International Mathematics and Science Study (TIMSS) menyatakan bahwa siswa indonesia berada di grade 8 pada bidang IPA yang menunjukan siswa indonesia peringkat 35 dari 49 negara Gonzales (Jayanti dkk, 2017). Berdasarkan pada permasalahan tersebut, menurut (Jayanti et al, 2017) proses pembelajaran yang masih berpusat pada guru, asumsi pemindahan pengetahuan yang dapat dipindahkan secara utuh dari pikiran guru kepada siswa tidak menjadikan siswa terlibat aktif, karena sebaiknya siswa sendiri yang harus membangun pengetahuannya dan pembelajaran berpusat kepada siswa (student centered). Permasalahan lain dalam pembelajaran IPA siswa tidak terbiasa menggunakan daya nalarnya tetapi justru terbiasa dengan cara menghafal dan hanya terpaku pada buku sumber, sehingga kemampuan siswa dalam mengembangkan keterampilan proses, memecahkan masalah dan membuat keputusan terbilang masih sangat rendah (Wahyuni, 2011).

Berdasarkan hasil studi pendahuluan yang telah dilaksanakan pada tanggal 4 oktober 2019 kepada siswa kelas V di MI Darul Ulum, terdapat permasalahan yang berkaitan dengan kemampuan berpikir kritis siswa pada pembelajaran IPA yaitu memberikan penjelasan sederhana (Elementary Clarification), siswa masih belum mampu memberikan penjelasan atau solusi dari permasalahan yang disajikan. Hal ini terlihat dari hasil jawaban siswa yang masih sederhana karena siswa hanya memindahkan jawabannya dari soal dan tidak mampu 
memberikan penjelasan lebih lanjut; kedua, berkaitan dengan membangun keterampilan dasar (basic support), hal ini ditunjukan dari hasil siswa ketika diberikan soal, bahwa siswa belum mampu menganalisis informasi atau permasalahan yang disajikan; dan ketiga, menyimpulkan (inference), siswa belum mampu menyimpulkan dari permasalahan yang diberikan, hal tersebut terlihat dari jawaban siswa yang hanya memindahkan jawaban dari soal. Selain permasalahan yang dihadapi siswa ketika mengisi soal uraian tersebut, setelah melakukan pengolahan data, jumlah siswa dari 21 orang, hasil yang didapatkan siswa ratarata mendapat nilai 25 namun hal tersebut belum mencapai kriteria yang diharapkan. Seperti yang dikatakan Trianto (Rosidi, 2016) bahwa kriteria nilai kemampuan dikatakan "baik" apabila mencapai angka $70 \leq \mathrm{T}<80$. Sehingga nilai rata-rata yang diperoleh dari hasil studi pendahuluan yaitu 31,9 dengan kriteria "Kurang Sekali".

Permasalahan tersebut menyebabkan perlu adanya upaya untuk meningkatkan kemampuan berpikir kritis siswa khususnya dalam pembelajaran IPA. Salah satu hal yang dipertimbangkan adalah pemilihan model pembelajaran yang tepat, pemilihan model pembelajaran juga harus disesuaikan dengan materi pelajaran yang disampaikan sehingga terciptanya proses pembelajaran yang aktif.

Model alternatif yang diasumsikan mampu meningkatkan kemampuan berpikir kritis siswa, salah satunya yaitu model pembelajaran Probing Prompting. Menurut Huda (Jamaludin, 2014) mengatakan bahwa model pembelajaran probing prompting merupakan suatu model pembelajaran yang mampu menuntun siswa untuk menggali gagasannya dengan memberikan pertanyaan-pertanyaan sehingga siswa mampu mengaitkan pengetahuan dan pengalaman dengan pengetahuan yang baru. Menurut Nurindahca (Hanggara \& Alfionita, 2013) bentuk pertanyaan yang diajukan dibedakan menjadi tiga bentuk yakni: a). susun ulang pertanyaan dengan kata-kata sederhana yang membawanya kembali ke pertanyaan awal. b). ajukan pertanyaan dengan kata-kata lain atau lebih sederhana dan disesuaikan dengan pengetahuan siswa. c). berikan gambaran umum tentang informasi yang diberikan dan pertanyaan yang akan membantu siswa agar ingat dan dapat menjawabnya.

Berbeda dengan Syamsuriyawati \& Setyawan (2019) yang mengatakan bahwa pembelajaran probing prompting merupakan model pembelajaran yang menuntun siswa untuk menggali pengetahuan baru yang didapatkannya dengan mengaitkan pengetahuan yang telah diperolehnya. Senada dengan Susanti (2017) bahwa model pembelajaran probing prompting yaitu pembelajaran yang dapat mengembangkan dan meningkatkan kemampuan berpikir kritis siswa, karena siswa ikut terlibat aktif secara langsung ketika proses pembelajaran.

Adapun langkah-langkah dalam model pembelajaran probing prompting menurut Lestari \& Yudhanegara (2017) terdiri dari:

1. Guru menghadapkan siswa pada suatu permasalahan.

2. Memberikan persoalan yang sesuai dengan tujuan pembelajaran kepada siswa.

3. Siswa diberikan kesempatan merumuskan jawaban.

4. Guru meminta salah satu siswa menjawab pertanyaan yang diberikan.

5. Apabila jawaban siswa benar, maka untuk meyakinkan jawaban tersebut guru menunjuk siswa lain untuk terlibat aktif. Namun, jika siswa mengalami kesulitan atau jawaban yang diberikan kurang tepat, guru mengajukan pertanyaan sebagai petunjuk penyelesaian jawaban.

Siswa diberikan pertanyaan akhir yang berbeda untuk lebih meyakinkan bahwa siswa sudah mencapai indikator yang diharapkan. 


\section{METODOLOGI}

Metode penelitian yang digunakan yaitu Penelitian Tindakan Kelas (PTK) sebanyak 2 siklus yang terdiri dari tahap perencanaan, pelaksanaan, observasi dan refleksi. Dengan pendekatan penelitian menggunakan pendekatan kualitatif dan kuantitatif, data kualitatif merupakan data yang diperoleh dari deskripsi lembar observasi yang digunakan untuk memberikan gambaran proses pembelajaran IPA melalui penerapan model probing prompting yang meliputi aktivitas guru dan siswa. Sedangkan data kuantitatif yaitu data yang berupa angkaangka dan bertujuan untuk memperoleh informasi mengenai data mengenai penerapan model probing prompting pada pembelajaran IPA melalui hasil tes IPA dan format lembar observasi. Sumber data dalam penelitian meliputi sumber data primer dan sumber data sekunder. sumber data primer diperoleh dari siswa kelas V MI Darul Ulum pada tahun ajaran 2019/2020 dengan jumlah siswa sebanyak 21 orang yang terdiri dari 8 siswa laki-laki dan 13 siswa perempuan. Sedangkan sumber data sekunder diperoleh dari guru wali kelas V MI Darul Ulum.

Teknik pengumpulan data pada penelitian ini menggunakan observasi dan juga tes. Observasi merupakan suatu pengamatan terhadap suatu objek untuk memperoleh suatu data dalam penelitian baik secara langsung maupun tidak langsung (Satori \& Komariah 2013). Kegiatan observasi dilakukan untuk mengetahui aktivitas siswa ketika proses pembelajaran dan untuk mengetahui sejauh mana kemampuan berpikir kritis siswa ketika proses pembelajaran, untuk mengetahuinya dilihat dari hasil perhitungan lembar observasi aktivitas guru dan siswa. Hasil pengamatan yang dilakukan di tulis dalam lembar observasi oleh peneliti dan dibantu oleh guru kelas ketika proses pembelajaran berlangsung. Sedangkan tes merupakan suatu cara untuk mengetahui keberhasilan pencapaian dengan cara mengukur dan menilai sesuai dengan tujuan yang telah ditetapkan (Hanifah, 2014). Pengumpulan data melalui teknik tes dilakukan dengan memberikan instrumen tes yang terdiri dari seperangkat pertanyaan soal untuk memperoleh data mengenai kemampuan siswa terutama pada aspek kognitif. Tes yang diberikan yaitu berbentuk tes uraian sebanyak 3 butir soal pada setiap masing-masing siklus.

\section{HASIL DAN DISKUSI}

Penelitian ini dilaksanakan di sekolah MI Darul Ulum Kabupaten Bandung, dimulai pada tanggal 11 Maret 2020 dan termasuk kegiatan pra siklus sekaligus tes awal untuk mengetahui kemampuan siswa yang dirasa masih rendah. Adapun subjek yang diteliti adalah siswa kelas V. Penelitian ini dilakukan dalam rangka memperbaiki kualitas pembelajaran, aktivitas belajar siswa dengan indikator kemampuan berpikir kritis pada pembelajaran IPA dengan menggunakan model pembelajaran probing prompting.

1. Kemampuan Berpikir Kritis Siswa MI Darul Ulum pada Pembelajaran IPA Sebelum Menggunakan Model Pembelajaran Probing Prompting

Hasil dari tes yang diberikan maka diperoleh rata-rata nilai kemampuan berpikir kritis siswa kelas V MI Darul Ulum pada materi ekosistem sebesar 35,29 dan nilai klasikal sebesar $4,76 \%$, hanya 1 orang siswa yang memperoleh nilai di atas nilai KKM yaitu 70. Berikut kemampuan berpikir kritis siswa sebelum menggunakan model probing prompting.

Tabel 1. Kemampuan awal siswa sebelum menggunakan model pembelajaran Probing Prompting

\begin{tabular}{ccc}
\hline Rata-rata & Persentase & Kriteria \\
\hline 35,29 & $4,76 \%$ & Kurang Sekali \\
\hline
\end{tabular}

Berdasarkan tabel 1, aktivitas mengajar terlihat meningkat pada setiap pertemuan, guru dalam hal ini berarti mampu memperbaiki kekurangan-kekurangan yang dilakukan ketika 
proses pembelajaran. Guru juga sudah mampu menerapkan model pembelajaran probing prompting pada pembelajaran IPA di kelas V MI Darul Ulum.

Kurangnya kemampuan berpikir kritis siswa disebabkan oleh beberapa faktor diantaranya yaitu kegiatan yang dilakukan siswa selama proses pembelajaran pada kegiatan pra siklus cenderung hanya mendengarkan penjelasan guru dan membaca buku sumber pembelajaran. Siswa belum terbiasa untuk menyampaikan pendapatnya, interaksi antara guru dan siswa di dalam kelas juga belum terbentuk, hal tersebut berpengaruh pada kemampuan berpikir kritis siswa. Hal ini dapat di duga mungkin model pembelajaran yang digunakan kurang tepat sehingga pembelajaran terlihat membosankan dan kurang efektif. Karena data tersebut diperoleh dari proses pembelajaran yang masih menggunakan metode konvensional atau ceramah.

Menurut Harsono dkk, (2009) metode ceramah adalah bentuk interaksi guru dan siswa di kelas melalui penuturan secara lisan, guru memberikan materi hanya berpaku pada sumber belajar sesuai yang ada di buku dan tidak memperhatikan keterlibatan siswa ketika proses pembelajaran, sehingga menjadikan pembelajaran kurang aktif karena siswa hanya mendengarkan. Metode ini kadang membosankan karena keterlibatan siswa terbatas dan siswa hanya mendengarkan tanpa melakukan oleh karena itu dalam praktiknya, keterampilan diperlukan untuk menarik perhatian siswa (Anas, 2014). Dapat disimpulkan bahwa metode ceramah atau konvensional kurang melibatkan siswa ketika proses pembelajaran, karena guru hanya bercerita dengan apa yang ada di buku dan menjadikan siswa kurang aktif ketika proses pembelajaran. Selain itu, siswa juga merasa jenuh ketika pembelajaran berlangsung karena guru guru tidak menggunakan metode yang bervariatif.

Melihat kondisi tersebut, maka pada siklus I dan siklus II dilakukan perbaikan dengan menggunakan model pembelajaran probing prompting pada pembelajaran IPA. Diharapkan dengan menggunakan model tersebut dapat mengubah proses pembelajaran menjadi lebih baik sehingga mampu meningkatkan kemampuan berpikir kritis siswa.

\section{Penerapan Model Pembelajaran Probing Prompting pada Pembelajaran IPA di Kelas V MI Darul Ulum pada Setiap Siklus}

Tahapan ini bertujuan untuk melihat proses pelaksanaan pembelajaran dengan menggunakan lembar observasi aktivitas belajar siswa dan aktivitas mengajar guru. Kegiatan aktivitas belajar siswa yang dimaksud dalam proses pelaksanaan penerapan model pembelajaran Probing Prompting ialah untuk melihat respon aktivitas siswa terhadap guru ketika mengajar. Sedangkan aktivitas mengajar guru disesuaikan dengan tahapan kegiatan pembelajaran yang terdapat pada RPP.

Penerapan model pembelajaran probing prompting pada pembelajaran IPA materi konsep perpindahan kalor dalam kehidupan sehari-hari sudah diterapkan dengan baik. Karena semua langkah-langkah pembelajaran terlaksana dengan baik sehaingga pada pelaksanannya guru sudah menguasai tahapan-tahapan menggunakan model pembelajaran probing prompting. Hal ini mengakibatkan naiknya aktivitas mengajar guru dan aktivitas belajar siswa selama proses pembelajaran pada setiap siklusnya.

Perolehan aktivitas guru dan siswa yang sudah dilaksanakan selama dua siklus selalu mengalami peningkatan. Aktivitas guru pada siklus I diperoleh rata-rata persentase sebesar $79,41 \%$ dan aktvitas siswa dengan rata-rata persentase $70,35 \%$, kemudian pada siklus II aktivitas mengajar guru mendapatkan persentase rata-rata sebesar $92,65 \%$ sedangkan untuk siswanya mendapatkan persentase $80,52 \%$. Berikut merupakan aktivitas hasil mengajar guru dan aktivitas belajar siswa yang disajikan dalam tabel 2 dan 3. 
Tabel 2. Persentase Peningkatan Aktivitas Guru

\begin{tabular}{|c|c|c|}
\hline Pertemuan & Keterlaksanaan & Kriteria \\
\hline Siklus I & $79,41 \%$ & Baik \\
\hline Siklus II & $92,65 \%$ & Sangat Baik \\
\hline
\end{tabular}

Tabel 3. Persentase Peningkatan Aktivitas Siswa

\begin{tabular}{lcc}
\hline \multicolumn{1}{c}{ Pertemuan } & Keterlaksanaan & Kriteria \\
\hline Siklus I & $70,35 \%$ & Baik \\
Siklus II & $80,52 \%$ & Baik \\
\hline
\end{tabular}

Peningkatan ini terjadi salah satunya yaitu karena pengaruh penerapan model pembelajaran probing prompting ketika pembelajaran. Karena model ini mendukung siswa untuk mengembangkan kemampuan berpikir kritisnya dimulai dari guru menyajikan masalah kemudian siswa menemukan sendiri dengan mencari informasi tambahan dan siswa melakukan percobaan untuk menguatkan pengetahuannya serta di dukung oleh media pembelajaran yang digunakan sehingga menjadikan siswa lebih aktif ketika setiap proses pembelajaran.

3. Kemampuan Berpikir Kritis Siswa Kelas V MI Darul Ulum pada Pembelajaran IPA Setelah Menggunakan Model Pembelajaran Probing Prompting pada Setiap Siklus

Berdasarkan hasil analisis kemampuan berpikir kritis siswa kelas V MI Darul Ulum dengan menggunakan model probing prompting pada pembelajaran IPA mengalami peningkatan di setiap siklusnya. Hal tersebut dapat dilihat dari hasil siklus I dan siklus I

Pada siklus I siswa memperoleh nilai rata-rata sebesar 49,06 dengan angka klasikal yang diperoleh yaitu 33,33\%. Pada siklus 1 hasil tes siswa masih rendah dan banyak siswa mendapatkan nilai di bawah KKM. Hal tersebut dapat dilihat dari hasil jawaban siswa pada gambar 1 .

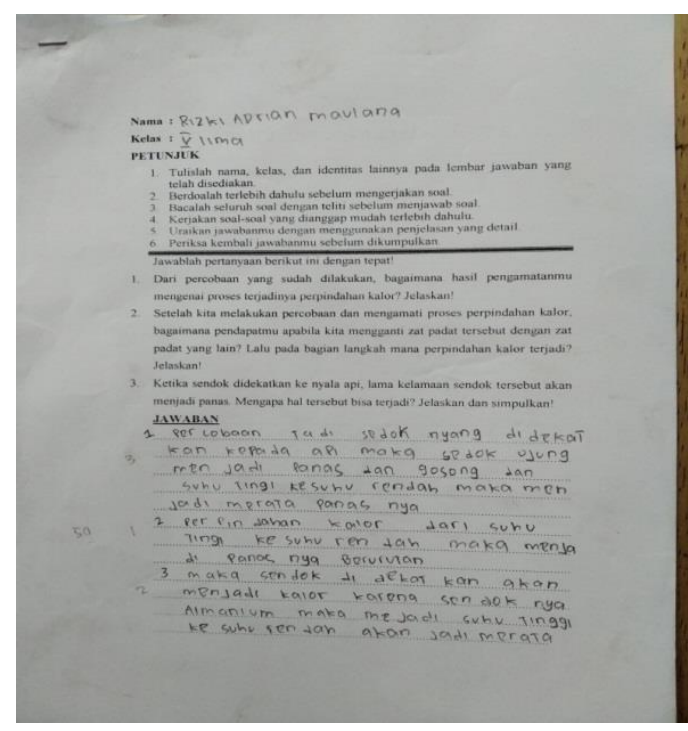

Gambar 1. Hasil Siswa (Siklus I)

Hasil yang diperoleh pada siklus I dirasa masih kurang karena apabila mengacu pada pedoman penilaian angka tersebut dikategorikan kurang. Untuk pembelajaran di siklus II angka klasikalnya sudah dikategorikan "Baik" yaitu dengan nilai klasikal yang diperoleh 
sebesar $66,67 \%$ dan rata-rata sebesar 61,11 . Hasil siswa pada siklus II dapat dilihat pada gambar 2.

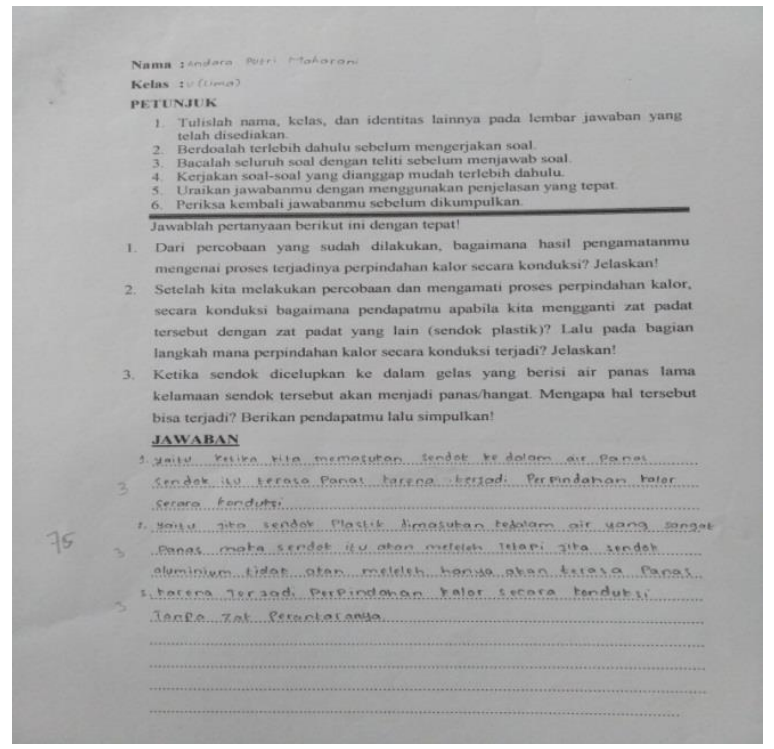

Gambar 2. Hasil Siswa (Siklus II)

Kenaikan itu dirasakan karena siswa cenderung lebih aktif ketika proses pembelajaran, aktivitas mengajar guru dilaksanakan secara rapih sesuai dengan RPP yang telah dibuat dengan menggunakan model pembelajaran probing prompting.

Model pembelajaran probing prompting merupakan model yang berorientasikan pada kontruktivisme karena model berkaitan erat dengan pertanyaan. Pertanyaan-pertanyaan yang disampaikan kepada siswa ditujukan untuk memotivasi dan memberikan isyarat kepada siswa dalam memahami serta menemukan jawaban dari permasalahan yang ada secara lebih mendalam sehingga siswa diarahkan agar mampu menyempurnakan ide-ide serta mampu menganalisis pendapat orang lain (Setiawati dkk, 2019). Selain itu juga, menurut Mutmainnah dkk, (2013) model probing prompting dapat mendorong keterlibatan siswa dan menciptakan lingkungan pembelajaran yang efektif. Apabila melihat beberapa pendapat tersebut, model probing prompting merupakan model efektif yang dapat meningkatkan kemampuan berpikir kritis siswa.

Dengan demikian berdasakan data yang disajikan, model pembelajaran probing prompting dapat digunakan karena mampu meningkatkan kemampuan berpikir kritis siswa di setiap siklusnya. Dengan demikian, hipotesis yang diajukan dapat terjawab bahwa penggunaan model pembelajaran probing prompting pada pembelajaran IPA dapat meningkatkan kemampuan berpikir kritis siswa.

\section{KESIMPULAN}

Berdasarkan hasil penelitian, maka dapat disimpulkan bahwa penerapan model pembelajaran probing prompting pada pembelajaran IPA terus mengalami peningkatan, hal tersebut dapat dibuktikan berdasarkan hasil yang diperoleh yaitu: kemampuan berpikir kritis siswa sebelum menggunakan model pembelajaran probing prompting terbilang rendah dengan nilai ratarata kelas yang diperoleh 35,29 dengan nilai ketuntasan klasikal yang diperoleh sebesar $4,76 \%$, karena tercatat hanya ada 1 orang siswa yang tuntas dari jumlah keseluruhan siswa 21 orang. Sedangkan keterlaksanaan lembar observasi aktivitas guru dan lembar observasi aktivitas siswa pada setiap siklusnya secara bertahap terus melakukan perbaikan-perbaikan, 
seperti hasil yang didaptkan pada siklus I aktivitas mengajar guru diperoleh dengan persentase $79,41 \%$ dan aktivitas belajar siswa diperoleh nilai persentase sebesar 70,35\%. Sedangkan pada siklus II keaktifan siswa meningkat dan siswa dapat melaksanakan model pembelajaran Probing Prompting dengan baik, persentase aktivitas belajar siswa mencapai 80,52\% dan aktivitas guru sebesar 92,65\%. Kemampuan berpikir kritis siswa dengan menggunakan model pembelajaran probing prompting pada pembelajaran IPA mengalami peningkatan. Hal ini berdasarkan hasil tes yang diberikan pada siklus I dan II diperoleh ratarata nilai sebesar 49,06 dan 61,11 dengan persentase ketuntasan belajar klasikal yang diperoleh pada siklus I dan II yaitu $33,33 \%$ dan $66,67 \%$.

\section{ACKNOWLEDGMENT}

Penulis mengucapkan terima kasih yang sebesar-besarnya untuk kedua pembimbing yaitu H. Yayan Carlian, M.Pd. dan Dede Rohaniawati, M.Pd. atas bimbingan yang diberikan serta wali kelas dan para siswa yang telah berkenan menjadi objek penelitin di masa pandemic Covid-19.

\section{BIBLIOGRAPHY}

Anas, M. (2014). Mengenal Metode Pembelajaran. Jakarta: Ciputat Pers.

Arifin, Z. (2017). Mengembangkan Instrumen Pengukur Critical Thinking Skills Siswa pada Pembelajaran Matematika Abad 21. Theorems, 1(2), 92-100.

Hanggara, Y., \& Alfionita, V. (2013). Eksperimentasi Model Pembelajaran Probing Prompting Dan Discovery Learning Terhadap Hasil Belajar Matematika Ditinjau Dari Minat Belajar Siswa Kelas VII SMP Negeri 3 Batam. Pythagoras, 4(2), 1-11. Hanifah, N. (2014). Memahami Penelitian Tindakan Kelas Teori dan Aplikasi. Bandung: UPI PRESS.

Harsono, B., Soesanto, \& Samsudi. (2009). Perbedaan Hasil Belajar Antara Metode Ceramah Konvensional dengan Ceramah Berbantuan Media Animasi pada Pembelajaran Kompetensi Perakitan dan Pemasangan Sistem Rem. Jurnal PTM, 9(2).

Hidayah, kurnia F., \& Suparman. (2019). Studi kebutuhan e-modul berbasis pbl untuk meningkatkan kemampuan berpikir kritis peserta didik, 5(1), 495-502.

Jamaludin. (2014). Belajar dan Pembelajaran. Bandung: CV. Insan Mandiri.

Jayanti, D., Arnyana, I. B., \& Gunamantha, I. M. (2017). Pengaruh Model Pembelajaran Sains Teknologi Masyarakat Terhadap Hasil Belajar IPA Ditinjau dari Literasi Digital Siswa Kelas V Sekolah Dasar Gugus VI Kecamatan Mengwi. Jurnal Pendidikan Dasar Indonesia, 1(2), 55-64.

Langrehr, J. (2006). Thinking Skill. Jakarta: PT Elex Komputindo Kelompok Gramedia.

Lestari, K. E., \& Yudhanegara, M. R. (2017). Penelitian Pendidikan Matematika. Bandung: PT Refika Aditama

Mutmainnah, S., Ali, M., \& Napitupulu, D. (2013). Penerapan Teknik Pembelajaran Probing -Prompting Untuk Meningkatkan Hasil Belajar Fisika pada Siswa Kelas VIII A SMP Negeri I Banawa Tengah, 2(1), 38-43.

Rosidi, M. I. (2016). Peningkatan Aktivitas dan Hasil Belajar Sejarah Melalui Penerapan Metode Pembelajaran Kooperatif Tipe Talking Stick pada Siswa Kelas -1 SMA Muhammadiyah 3 Jember, (12). 1.

Sari, D. S., Widiyawati, Y., \& Nurwahidah, I. (2018). Pengembangan Instrumen Integrated Science Test untuk Mengukur Kemampuan Berpikir Kritis Peserta Didik SMP, 1(1), $1-9$. 
Setiawati, D. A. O., Sudiarta, I. G. P., \& Ardana, I. M. (2019). Pengaruh Model Pembelajaran Probing Prompting Berbantuan Index Card Match Terhadap Prestasi Belajar Matematika Siswa Kelas X SMA Negeri 1 Sukasada. Jurnal Pendidikan Dan Pembelajaran Matematika Indonesia, 8(1), 71-81.

Suparya, I. K. (2018). Pengaruh Model Pembelajaran Kooperatif Tipe Think Talk Write (TTW) Terhadap Hasil Belajar dan Kemampuan Berpikir Kritis pada Pembelajaran IPA di Sekolah Dasar. Widyacarya, 2(2), 19-24.

Susanti, E. (2017). Penerapan Model Pembelajaran Probing-Prompting Untuk Meningkatkan Kemampuan Berpikir Kritis Matematis Siswa Kelas XI.IPA MAN 1 Kota Bengkulu. Raflesia, 2(1).

Susilawati, W. (2012). Konsep Dasar Matematika. Bandung: Tidak Diterbitkan.

Syamsuriyawati, \& Setyawan, D. (2019). Efektivitas Pembelajaran Matematika Melalui Penerapan Model Pembelajaran Probing-Prompting Pada Siswa Kelas VII.A SMP Hang Tuah Makassar. Jurnal Ilmiah Pendidikan Matematika, 2(1), 10-17.

Wahyuni, S. (2011). Mengembangkan keterampilan berpikir kritis siswa melalui pembelajaran ipa berbasis Problem-Based Learning.

Widani, N. K. T., Sudana, D. N., \& Agustiana, I. G. A. T. (2019). Pengaruh Model Pembelajaran Inkuiri Terbimbing Terhadap Hasil Belajar IPA dan Sikap Ilmiah pada Siswa Kelas V SD Gugus I Kecamatan Nusa Penida. Journal of Education Technology, 3(1), 15-21.

Wijaya, E. Y., Sudjimat, D. A., \& Nyoto, A. (2016). Transformasi Pendidikan Abad 21 Sebagai Tuntutan Pengembangan Sumber Daya Manusia di Era Global, 1, 263-278.

Yulianti, Y. (2017). Literasi Sains dalam Pembelajaran IPA. Jurnal Cakrawala Pendas, 3(2), 21-28. 